\title{
CCE Intercomparison of AC-DC Transfer Standards
}

\author{
Jan P. M. de Vreede
}

\begin{abstract}
A worldwide intercomparison is described covering both ac voltage and ac current measurements in the frequency range from $40 \mathrm{~Hz}$ to $1 \mathrm{MHz}$. Results are consistent within 10-20 ppm at low voltage and frequency, but differ by up to $100 \mathrm{ppm}$ at high voltage and frequency. For currents of tens of milliamperes the results are consistent within $40 \mathrm{ppm}$.
\end{abstract}

\section{INTRODUCTION}

$\mathrm{T}$ HE traceability of ac quantities is becoming more important with the introduction of advanced measurement equipment capable of covering wide ranges in both frequency and amplitude. Modern electronic equipment now requires accuracy of national standards at a level between 1 and $10 \mathrm{ppm}$.

Thermal converters are usually used at national standards laboratories as basic standards, at a level of a few volts, currently up to at least $1 \mathrm{MHz}$. For higher voltages, series resistors are used to extend the range of the standard.

A small-scale intercomparison between four national standards laboratories (IMM, ETL, NBS, and NPL) was organized under the auspices of the Comite Consultatif d'Électricité (CCE) in the seventies. The results were published in 1980 [1]. Because of the high degree of consistency (of the order of $10 \mathrm{ppm}$ ) the CCE decided to organize a large-scale intercomparison for ac quantities with the Van Swinden Laboratorium (VSL) as pilot laboratory.

The scope of the comparison was to cover the usual range of ac-dc standards available at national standards laboratories. Hence, a frequency range from $40 \mathrm{~Hz}$ up to $1 \mathrm{MHz}$ has been chosen, as well as higher voltages. This paper describes the results of this intercomparison in which a total of 13 laboratories from all over the world participated.

\section{Organization of the INTERCOMParison}

The intercomparison is divided into two main rounds, one confined to western Europe and one extending worldwide. The first round was carried out under a contract with BCR (Community Reference Bureau, part of the Commission of the European Communities) from 1981 to 1986. During this period the transfer standards were returned to VSL twice for checking and repair. The devices were hand-carried.

Manuscript received June 11, 1992; revised September 11, 1992.

The author is with NM: Van Swinden Laboratorium, $2600 \mathrm{AR}$ Delft, The Netherlands.

IEEE Log Number 9207006.
The second round started after writing the intermediate BCR report [2] and after an upgrading of the VSL facilities. This round covers the period from 1988 to the beginning of 1992. The transfer devices were returned twice to VSL for intermediate measurements and were transported using standard air-freight procedures.

\section{Traveling Devices}

As VSL did not have sufficient traveling standards available, both the National Physical Laboratory (NPL, UK) and the National Bureau of Standards (NBS, US; now National Institute of Standards and Technology (NIST)) provided the necessary standards. A set of seven traveling standards has been identified to cover the voltage range between 10 and $1000 \mathrm{~V}$ and the current range from 10 to $30 \mathrm{~mA}$. In Table I the measurement voltage/current and frequencies are indicated, as well as those for the earlier comparison [1].

\section{A. Stability of the Traveling Devices}

The thermal elements are rather fragile and therefore the method of transport has been a point of concern. In the first round the items were hand-carried (i.e., transported under the care of laboratory personnel). In practice, the actual handling during measurements led to most of the damage. In the second round, where air-freight handling was unavoidable, the first transport package was not sufficiently rigid to permit secure transport and some components were damaged. After that there was only one incident of damage. The following is a summary of the problems with the devices. PTB found poor electrical insulation between heater and thermocouple in the $10-\mathrm{mA}$ converter (replaced by NPL before VSL-82). LCIE experienced a failure of the 30-mA converter: VSL replaced it with a $30-\mathrm{mA}$ device (10 $\mathrm{mA}+$ shunt). SMB experienced a break-down of the 5-mA converter which effectively terminated the measurements on the $10 \mathrm{~V}$ to $300 \mathrm{~V}$ ranges (replaced by VSL before last measurements of the first round). The 1000-V converter failed at VNIIM.

\section{Laboratory Procedures and Standards}

In the guidelines for the intercomparison the basic setup is detailed using the supplied GR874 Tee-connector for connecting the ac and dc source to the laboratory standard and to the traveling standard (they have either a GR874 or a GR900 connector; for the latter an adapter has been supplied). The quantity to be measured is the ac-dc difference of the traveling standards at the reference plane 
TABLE I

Transfer Standards and Measurement Parameters: (In Brackets: Origin of Device: Underlined FREQUENCIES ALSO USED IN [1])

\begin{tabular}{|c|c|c|c|}
\hline $\begin{array}{l}\text { Voltage } \\
\text { Nominal value }\end{array}$ & Range resistor & Thermal element & $\begin{array}{c}\text { Measurement frequencies } \\
(\mathrm{kHz})\end{array}$ \\
\hline $10 \mathrm{~V}$ & $1.9 \mathrm{k} \Omega(\mathrm{NPL})$ & $5 \mathrm{~mA}(\mathrm{NPL})$ & $\underline{0.040,20,50,100,1000}$ \\
\hline $30 \mathrm{~V}$ & $6 \mathrm{k} \Omega(\mathrm{NPL})$ & $5 \mathrm{~mA}$ (NPL) & $0.040,20,50,100$ \\
\hline $100 \mathrm{~V}$ & $20 \mathrm{k} \Omega(\mathrm{NPL})$ & $5 \mathrm{~mA}(\mathrm{NPL})$ & $0.040,20,50,100$ \\
\hline $\begin{array}{r}300 \mathrm{~V} \\
1000 \mathrm{~V}\end{array}$ & $60 \mathrm{k} \Omega$ (NBS) & $\begin{array}{l}5 \mathrm{~mA} \text { (NPL) } \\
\text { Integrated device (NBS) }\end{array}$ & $\begin{array}{l}0.040,20,50,100 \\
0.040,20,50\end{array}$ \\
\hline \multicolumn{4}{|l|}{$\begin{array}{l}\text { Current } \\
\text { Nominal value }\end{array}$} \\
\hline $\begin{array}{l}10 \mathrm{~mA} \\
30 \mathrm{~mA}\end{array}$ & $\begin{array}{l}10 \mathrm{~mA} \text { (NPL) } \\
30 \mathrm{~mA}(\mathrm{NPL})\end{array}$ & & $\begin{array}{l}\frac{0.040,20,50,}{0.040,20,50}, 100 \\
\underline{0.00}\end{array}$ \\
\hline \multicolumn{4}{|l|}{ Accessories: } \\
\hline \multicolumn{4}{|c|}{$\begin{array}{l}\text { GR874 Tee connector } \\
\text { GR874-GR900 adaptor } \\
\text { The accessories have been chosen to fit the usual connector types }\end{array}$} \\
\hline
\end{tabular}

which is defined as the midplane of the Tee-connector. A reference plane has been defined, because for high frequencies the distance between this plane and the device itself may become significant.

The ac-dc difference $\delta$ is defined as follows:

$$
\delta=\left(X_{\mathrm{ac}}-X_{\mathrm{dc}}\right) / X_{\mathrm{dc}}
$$

where $X_{\mathrm{dc}}$ is the average of the two directions of dc quantities to produce the same output voltage as the ac quantity $\boldsymbol{X}_{\mathrm{ac}}$.

All laboratories used a sequence of alternately supplying the necessary signals (either $\mathrm{ac} / \mathrm{dc}+/ \mathrm{dc}-/ \mathrm{ac}$ or $\mathrm{dc}+1$ $\mathrm{ac} / \mathrm{dc}-$ ), where $\mathrm{dc}+$ and $\mathrm{dc}-$ are signals of (approximately) equal size but reversed polarity. From the latter two the reference signal is determined. A measurement usually consists of a series of such cycles.

For each signal input the thermal outputs of the laboratory standard and traveling standard are determined by measuring directly the outputs, separately, or by measuring their difference and measuring directly one output. The latter method is primarily employed when a setup is used for which the source instabilities are compensated by means of a divider so as to obtain the same output for both devices (see, e.g., [3]). In general, dc and ac source amplitudes are adjusted in such a manner that the thermal converter output for ac falls between the two dc outputs.

Usually external thermal insulation of the thermal converters is used to attenuate ambient temperature variations. ETL and NIST examined temperature dependence, but did not find a significant relation.

The relevant ac and dc signals are calculated by linear or cubic polynomal interpolation so as to obtain equivalent readings at the same moment in time during the measurement cycle. At higher frequencies, usually $1 \mathrm{MHz}$, comparisons on consistency have been carried out at several laboratories using a calorimetric method.

\section{A. Participating Laboratories and Personnel}

In this section the participating laboratories, the personnel directly involved in the comparison and some special features of the laboratory setup are given (more details about the facilities of the west European laboratories are found in [2] and its references). Also indicated in the text by " ***" are those laboratories which participated in the earlier comparison [1]. In Table II the time schedule is presented as well as when the "breakdown" in a traveling device occurred.

National Physical Laboratory (NPL**), Teddington, U.K.: B. R. D. Knight, P. Martin

Instead of a simple interpolation per cycle of ac and dc signals a software program is used to obtain one complete fit for the whole set of cycles within one run. A measurement system with source instability compensation is used. The standards are similar to the traveling devices.

$$
\begin{aligned}
& \text { Physikalisch-Technische Bundesanstalt (PTB), } \\
& \text { Braunschweig, Germany: M. Klonz }
\end{aligned}
$$

The measuring devices are used in combination with another thermal element in order to compensate for drift. The dc-input into the latter element is adjusted to maintain a null reading between the two thermal element outputs. This adjusted dc voltage is used as measurement result in the measurements. The references are multijunction thermal converters (MJTC; nominal 3-V input; developed at PTB by Klonz [4]). They are very well evaluated for both voltage and current transfer. For $30 \mathrm{~mA}$ a single junction thermal element with built-in shunt is used after having been calibrated against a MJTC.

Istituto Elettrotecnico Nazionale Galileo Ferraris (IEN), Torino, Italy: F. Cabiati

A differential measurement system is used for measuring the output of one converter and the difference between 
TABLE II

Time SChedule of the International Comparison DAMAGES INDICATED!

\begin{tabular}{ll}
\hline Round 1: & \\
1: VSL: & July 1980-Oct. 1980 \\
2: NPL: & Nov. 1980-Mar. 1981 \\
3: PTB: & Apr. 1981-Sept. 1981 \\
4: VSL: & Oct. 1981-Apr. 1982 (10 mA replaced by NPL) \\
5: IEN: & May 1982-Feb. 1983 \\
6: LCIE: & Mar. 1983-Jan. 1984 (failure $30 \mathrm{~mA})$ \\
7: VSL: & Feb. 1984-Mar. 1984 \\
8: IIRS: & Apr. 1984-July 1984 \\
9: SMB: & Aug. 1984-Feb. 1985 (failure 5 mA) \\
10: VSL: & Mar. 1985-Oct. 1985
\end{tabular}

Reports received in Jan. 1986/BCR report Aug. 1987

Round 2:

$\begin{array}{ll}\text { 1: VSL: } & \text { Aug. } 1988 \\ \text { 2: ETL: } & \text { Jan. 1989-Mar. } 1989 \\ \text { 3: CSIRO: } & \text { Apr. 1989-July } 1989\end{array}$

(elsewhere but no data received) Aug. 1989-Oct. 1989

$\begin{array}{ll}\text { 4: VSL: } & \text { Nov. 1989-Dec. } 1989 \\ \text { 5: NRC: } & \text { Jan. 1990 } \\ \text { 6: NIST: } & \text { Feb. 1990-Apr. } 1990 \\ \text { 7: VSL: } & \text { May 1990-June 1990 } \\ \text { 8: ASMW: } & \text { July 1990-Oct. } 1990 \\ \text { 9: VNIIM: } & \text { Nov. 1990-Oct. 1991 (failure 1000 V) } \\ \text { 10: VSL: } & \text { Nov. 1991-Feb. } 1992\end{array}$

Reports received Nov. 1991/Paper spring 1992

the two devices. A set of six thermal elements (TE; 1, 2, $4 \mathrm{~V}$, and 3 different currents) is used as basic reference. The average ac-dc difference of this group is defined to be zero.

Laboratoire Central des Industries Électriques (LCIE), Fontenay-aux-Roses, France: M. Knosp

A compensated, manual system with both linear and polynomial interpolation have been used. Standards have been evaluated at low frequency with "crest detectors" and at high frequencies with bolometers ( $1 \mathrm{MHz}$ ).

IIRS, Dublin, Ireland: J. O'Gara, M. A. Hynes

A semi-automated system employing a relay switch is used. Outputs are measured in sequence (not simultaneously) and no attempt is made to compensate for source variations. The standards set is a commercial product calibrated at NBS.

Service Metrologie Belge (SMB), Brussels, Belgium: J. Nicolas, N. Voorhof

A balancing system is used which allows direct comparison between MJTC and single junction thermal converters (SJTC). Up to $100 \mathrm{~V}$ the system is operated under computer control, above $100 \mathrm{~V}$ in a semi-automated way because a manually operated switch has to be used. PTBtype MJTC's are used as references. At $1 \mathrm{MHz}$ a group of commercial thermal converters and a locally made device are used. For $30 \mathrm{~mA}$ a set of TE's is calibrated against the MJTC.

Electrotechnical Laboratory (ETL **), Tsukuba, Japan: K. Shida, G. Yonezaki, T. Nemoto
A new measurement facility (using differential voltage measurement) is used for this intercomparison. All standards (having type- $\mathrm{N}$ connectors) are $10 \mathrm{~mA}$ thermal converters housed in an almost cubic cylinder. A group of six converters forms the reference group of which the average is assumed to be zero (based upon pair difference measurements of each combination). The 30-mA converter is compared to a set of three $10-\mathrm{mA}$ converters connected in parallel.

Commonwealth Scientific and Industrial Research

Organization (CSIRO), Lindfield, Australia: K. G.

Kujath

Standards are based upon a set containing single-junction converters which have been extensively analyzed in the past. The working group references are commercial items which are compared to the basic group by using a buildup chain over the full voltage range $(1-1000 \mathrm{~V})$ from 57 $\mathrm{Hz}$ to $100 \mathrm{kHz}$. At $1 \mathrm{MHz}$ a successful comparison was carried out between calculation (using material information) and a calorimetric method.

In each output channel a Lindeck potentiometer with nulling detector is used followed by an A/D-converter. 46 runs, each of 10 measurements, are performed during a period of three months (The laboratory standards have been attached an equal number of runs to each side of the Tee-junction)

National Research Council (NRC), Ottawa, Canada: R. F. Clark

The reference standards are 1-V calorimetric TVC's [5] with commercial working standards used in the intercomparison. Measurements have carried out at below nominal rating. Three runs have been made. No measurements have been carried out below $50 \mathrm{kHz}$.

National Institute of Standards and Technology (NIST ${ }^{* *}$ ), Gaithersburg, USA: J. Kinard

A set of eight MJTC's is used as NIST set with an average ac-dc difference of less than $0.5 \mathrm{ppm}$ between $30 \mathrm{~Hz}$ and $10 \mathrm{kHz}$. Buildup, standards, and uncertainties $(2 \sigma)$ are described in [6]. Different setups have been used. A weighted average is used as final result, except for 1000 V. The ambient temperature varied between 22 and $27^{\circ} \mathrm{C}$, but no influence on the results has been observed.

Amt für Standardisierung, Me $\beta$ wesen und Warenprüfung (ASMW), Berlin, Germany ${ }^{1}$ : G. Schliestedt

A MJTC of $10 \mathrm{~mA}$ and a SJTC of $2.5 \mathrm{~mA}$ combined with range resistors are used as standards. The set of standards include a manually operated transfer switch between the two sources (dc and ac). The measurement system is equipped with UHF connectors and hence a different reference plane is used. Up to $100 \mathrm{kHz}$ the influence of this change in reference plane is assumed to be negligible.

'The measurements were performed before the German unification. ASMW is now integrated with PTB. 
D. I. Mendeleyev Institute for Metrology (VNIIM **), St. Petersburg, Russia: O. P. Galakhova, M. S. Beliaieva, G. P. Telitchenko, V. M. Baikov

The standards are multijunctions (in air) housed coaxially in a metal cylinder. Metal-dielectric thin-film resistors are used to extend the range from 10 to $1000 \mathrm{~V}$. For $1 \mathrm{MHz}$ and $10 \mathrm{~V}$ a single junction TE and resistor is used. A special amplifier is used for the current ac-dc transfer.

The laboratory reference is maintained at fixed output amplitude for both ac and dc. In the laboratory definition of the ac-dc difference the numerator has the opposite sign compared to other results. The pilot laboratory has converted these data to obtain a consistent set for all participants.

Van Swinden Laboratorium (VSL), Delft, The Netherlands: C. J. P. M. Harmans, J. J. Schmitt, J. T. Dessens, J. P. M. de Vreede

Because VSL as pilot laboratory has regularly made measurements during the last decade, the evolution in its transfer standards and its measuring facilities can be shown in the description of the setups used in rounds 1 and 2 . In the first round commercially obtained units (calibrated at NBS) were used as standards with SJTC " homemade" devices as working standards (5-mA TE plus range resistors in home-made configurations). For current measurements a group of $5 \mathrm{~mA}$ (different mounted with low dc-reversal error) TE's are used and are given a zero difference. In the second round the standards have changed and are now MJTC's obtained from PTB, but mounted in a cylindrical housing. These have been used directly as voltage and current standards. An evaluation of the standards was undertaken after the first round, because there seemed to be some systematic deviations in the VSL standards. This was confirmed with the new MJTC's. Hence, in the second round the values from the new standards are used (leading to incremental variations in the VSL results between round 1 and 2). At the end of 1991, a new evaluation had taken place for the MJTC, resulting in a change of less than $2 \mathrm{ppm}$. The newly developed $1 \mathrm{MHz} \mathrm{HF}$ ac/dc converters (with calculable acdc transfer) were used [7]. The basic measuring setup includes a fully automated transfer system, with built-in facilities to obtain settings for the compensation parameters.

The output signals were processed differently in each round. In the first round, a system was used in which converter output and difference output (using pre-amplification to a normal DMM) were obtained in sequence. In the second round, part of the measurements has been performed using a new setup with direct readout of two DMMs with sufficient resolution after amplification. The remainder of the measurements were performed using the older system. Altogether it has resulted in a more stable measuring facility.

\section{RESULTS OF THE INTERCOMPARISON}

Figs. 1-7 give an overview of the results for each traveling standard. The figures are subdivided according to frequency: a) $40 \mathrm{~Hz}$; b) $20 \mathrm{kHz}$; c) $50 \mathrm{kHz}$; d) $100 \mathrm{kHz}$; e) $1 \mathrm{MHz}$. The $\mathrm{X}$ axis is a time scale (in years from January 1,1980 ) with the measurement value near the endpoint of the measuring period of each laboratory (pilot laboratory indicated by $(+)$; the numbers refer to Table II). All the data (ac-dc difference in parts per million) are based on an analysis by the pilot laboratory and represent the information provided by each participant at the time of measurement. This latter point has to be emphasized because of the long time span involved. The uncertainty stated here (vertical bars refer to stated $1 \sigma$ total uncertainty) might differ significantly from their present capabilities. A dash-dot line in a figure indicates a failure in the traveling standard at that time.

First we look at the data itself, with emphasis on the VSL values. The jumps for the $10-\mathrm{V}$ device at 50 and 100 $\mathrm{kHz}$ are due to changes in the VSL-references; also note the $30-\mathrm{V}$ device at $100 \mathrm{kHz}$.

For the $1000-\mathrm{V}$ device at $50 \mathrm{kHz}$ there seem to be two separate groupings about $50 \mathrm{ppm}$ apart. Further investigation is necessary because the stability of this converter was not good. This may be due to some small movement of the range resistor. The last VSL data is obtained after repair of the converter which failed during measurements at the last participant.

The $5 \mathrm{~mA}$ device (part of all devices from 10 to $300 \mathrm{~V}$ ) failed during measurements at the last participant of round 1. The last set of VSL data of round 1 are obtained after repair of the device and hence they might be combined with the results obtained in the second round.

The $30-\mathrm{mA}$ converter failed during the first round. The jump in the data (for $100 \mathrm{kHz}$ ) is clearly linked with its replacement.

Because of the extended time and differing contributors the mean and spread for all samples is calculated for each transfer standard. All data from VSL within each round are treated as one entry for the calculation of the mean. The results are presented in Table III as well as in the Figs. 1-7 (the mean value is given by a solid line). The overall results are quite good, the spread being about the same as claimed by an individual laboratory. However, looking more carefully to the contributing sources of uncertainty the laboratories' standards play a significant role in this budget and also the basic uncertainties in the transfer process (going from e.g., 4-100 V typically involves five steps). Therefore, in Table IV an overview is presented of the ratio of the type A to the type B uncertainties, an indication of the relative importance of the statistical variance in the measurements to the standards uncertainty and transfer uncertainty.

It suggests that a better evaluation of the standards and/ or improved design would appear to be the most necessary requirement. Recent steps in this direction have been described in [4], [7]-[9]. 
DE VREEDE: AC-DC TRANSFER STANDARDS

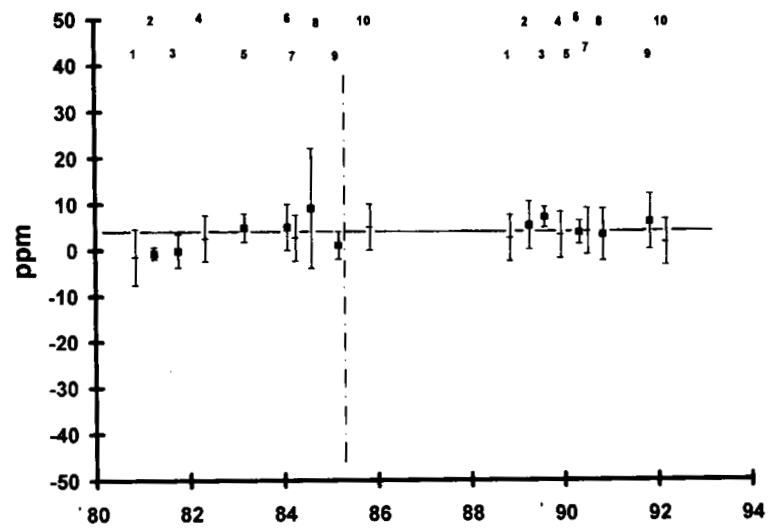

(a)

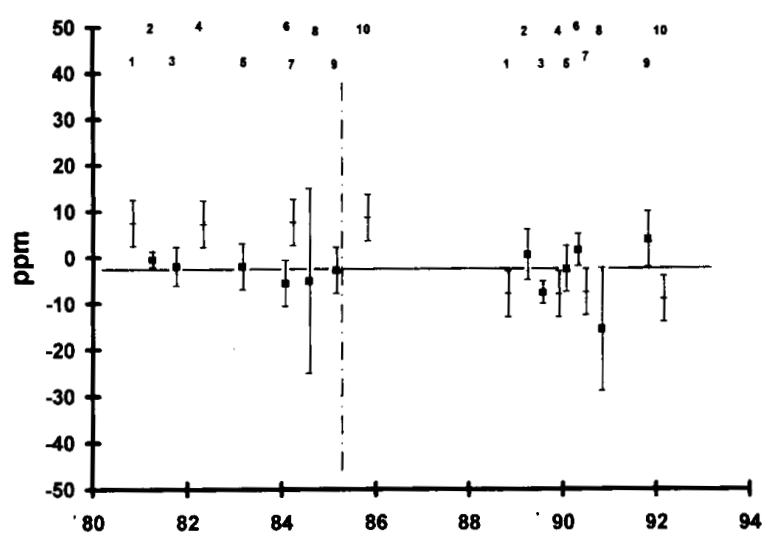

(c)

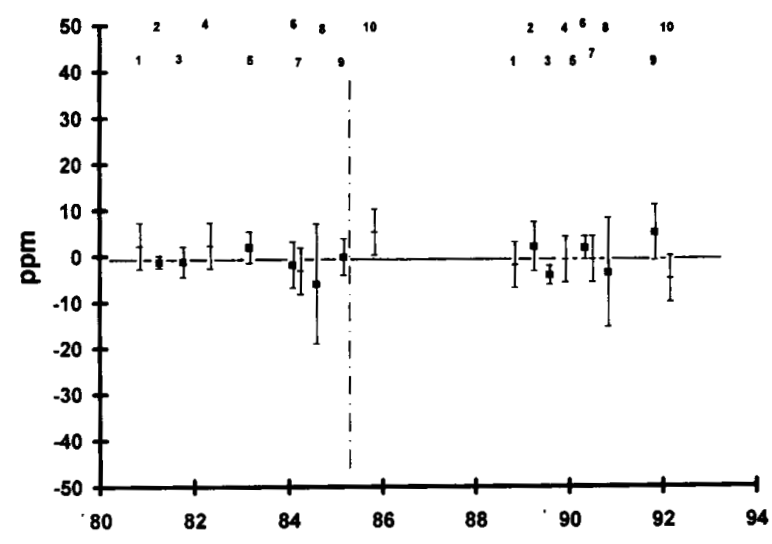

(b)

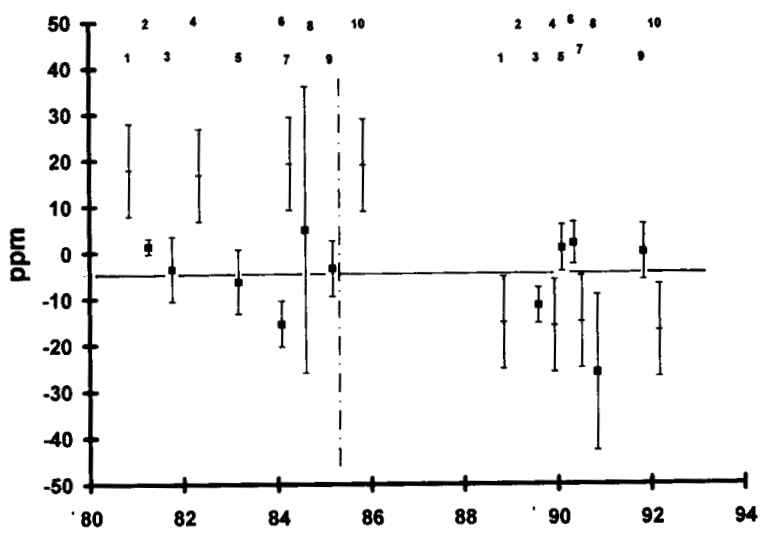

(d)

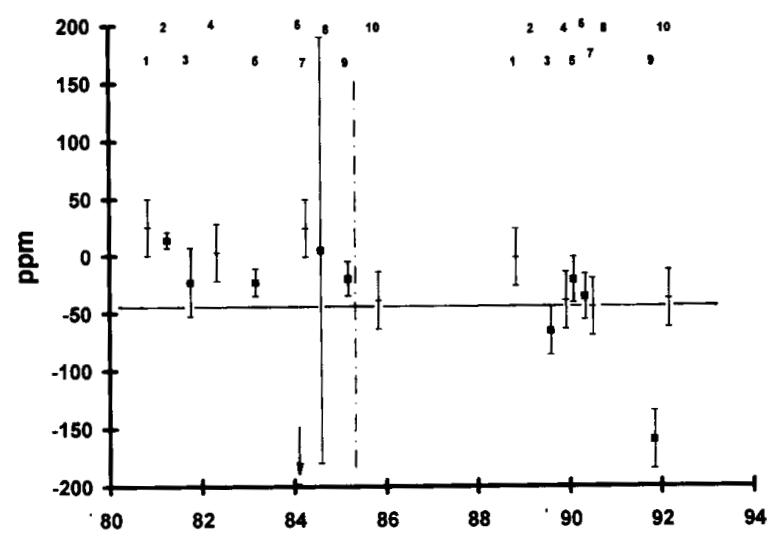

(e)

Fig. 1. AC-DC difference for the 10-V standard as measured by each laboratory (vertical bars refer to stated $1 \sigma$ total uncertainty). (a) $40 \mathrm{~Hz}$. (b) 20 kHz. (c) $50 \mathrm{kHz}$. (d) $100 \mathrm{kHz}$. (e) $1 \mathrm{MHz}$. 


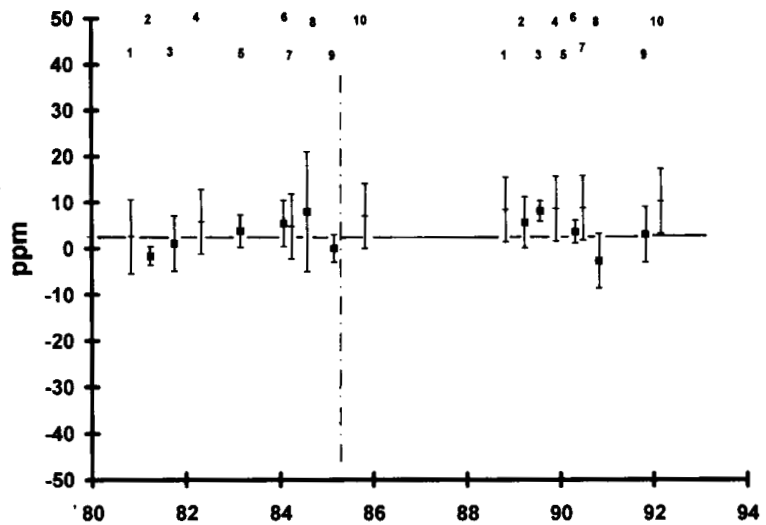

(a)

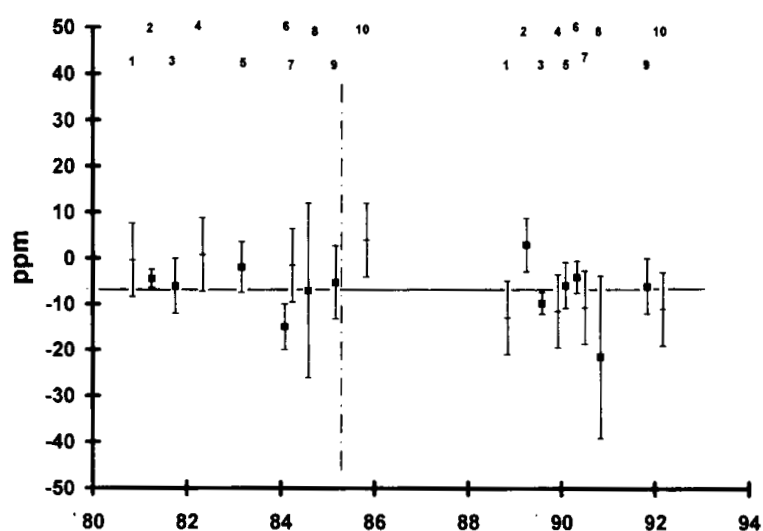

(c)

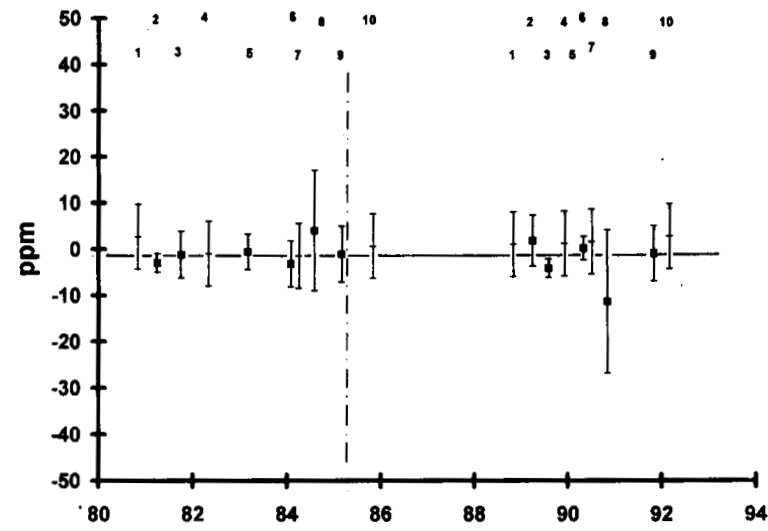

(b)

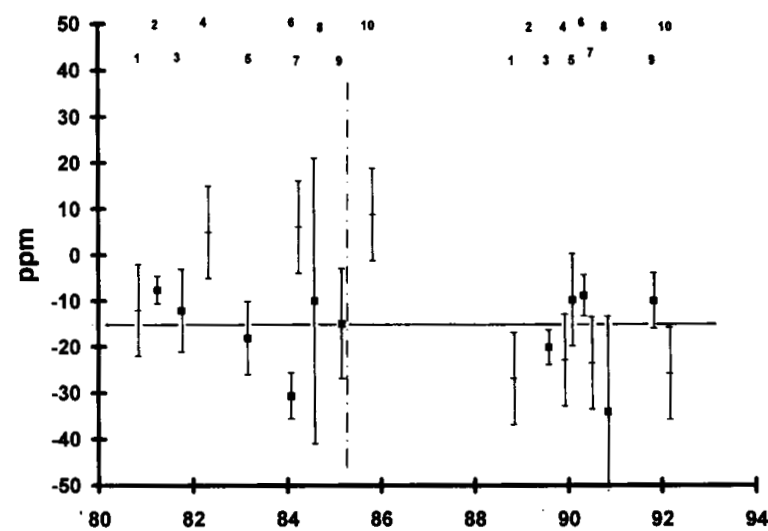

(d)

Fig. 2. AC-DC difference and total uncertainty (vertical bar: $1 \sigma$ ) for the $30-\mathrm{V}$ standard as measured by each laboratory. (a) $40 \mathrm{~Hz}$. (b) $20 \mathrm{kHz}$. (c) $50 \mathrm{kHz}$. (d) $100 \mathrm{kHz}$.

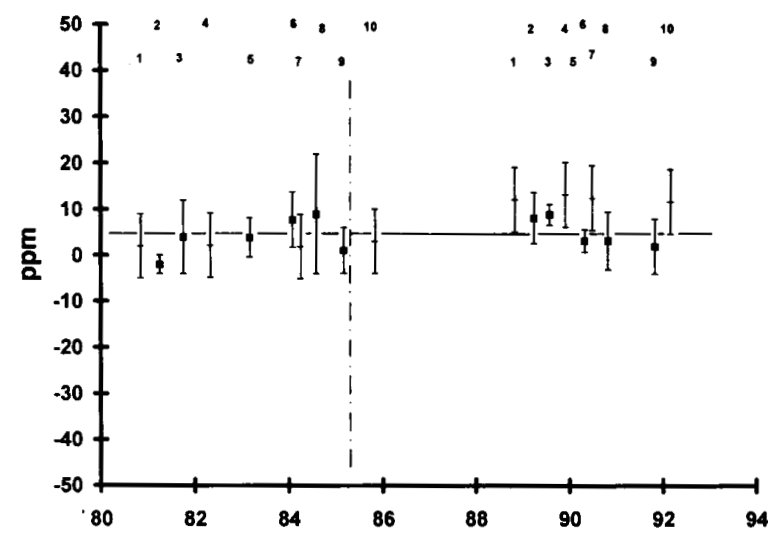

(a)

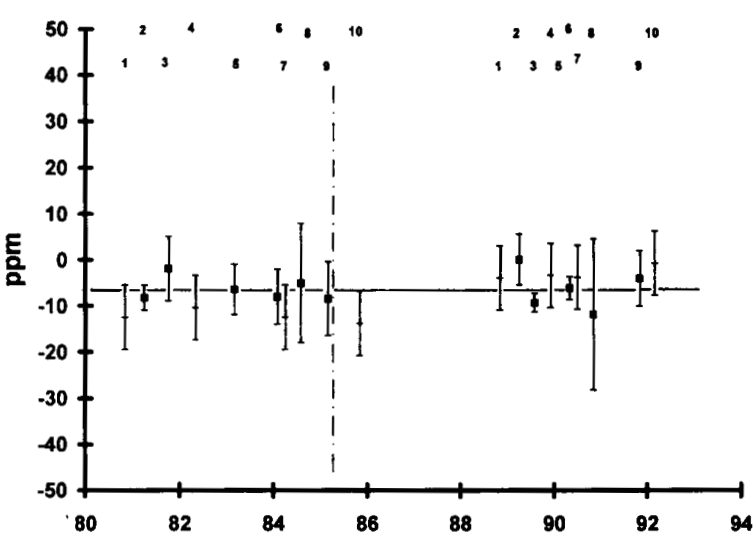

(b)

Fig. 3. AC-DC difference and total uncertainty (vertical bar: $1 \sigma$ ) for the 100 -V standard as measured by each laboratory. (a) $40 \mathrm{~Hz}$. (b) $20 \mathrm{kHz}$. (c) $50 \mathrm{kHz}$. (d) $100 \mathrm{kHz}$ 
DE VREEDE: AC-DC TRANSFER STANDARDS

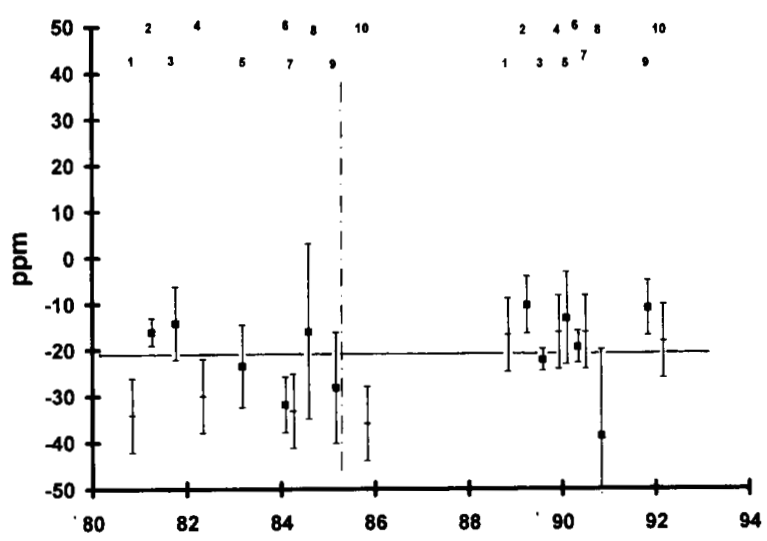

(c)

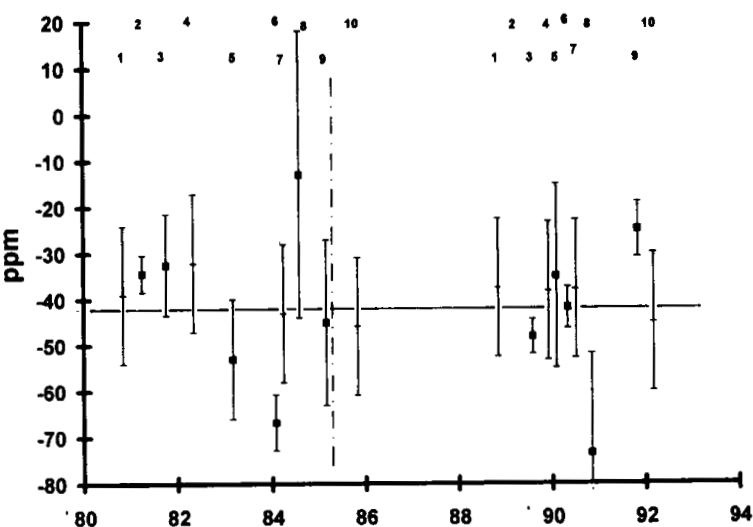

(d)

Fig. 3. (Continued.)

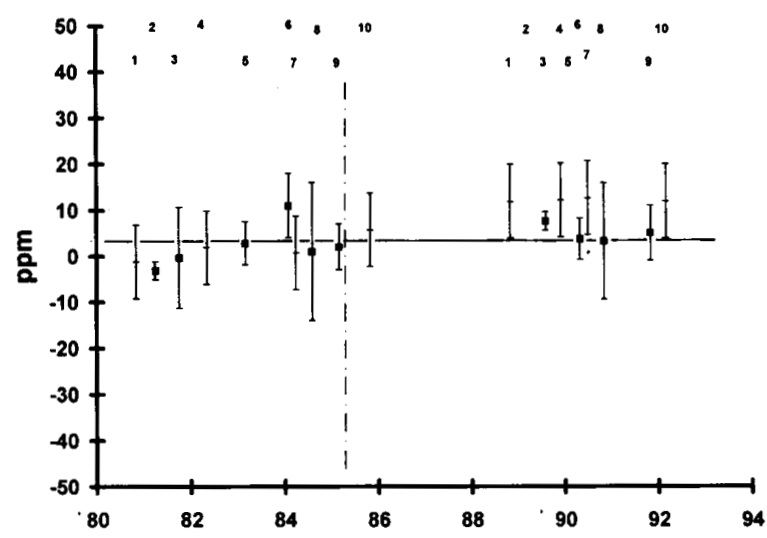

(a)

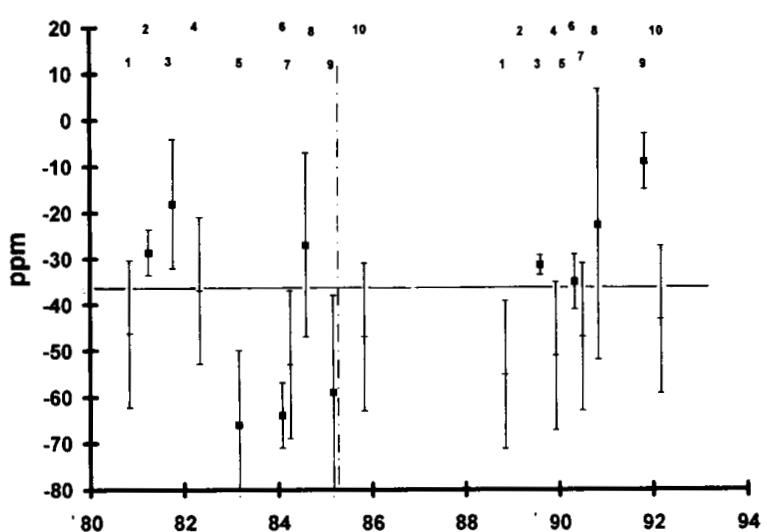

(c)

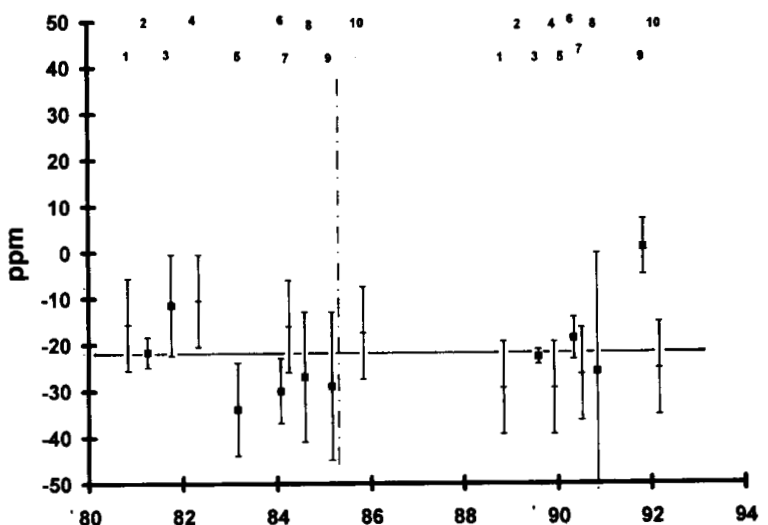

(b)

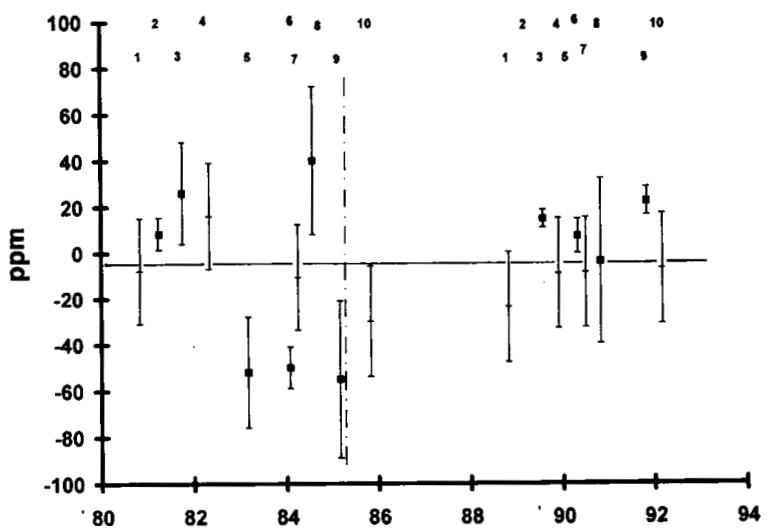

(d)

Fig. 4. AC-DC difference and total uncertainty (vertical bar: $1 \sigma$ ) for the $300 \mathrm{~V}$ standard as measured by each laboratory: (a) $40 \mathrm{~Hz}$. (b) $20 \mathrm{kHz}$. (c) $50 \mathrm{kHz}$. (d) $100 \mathrm{kHz}$. 


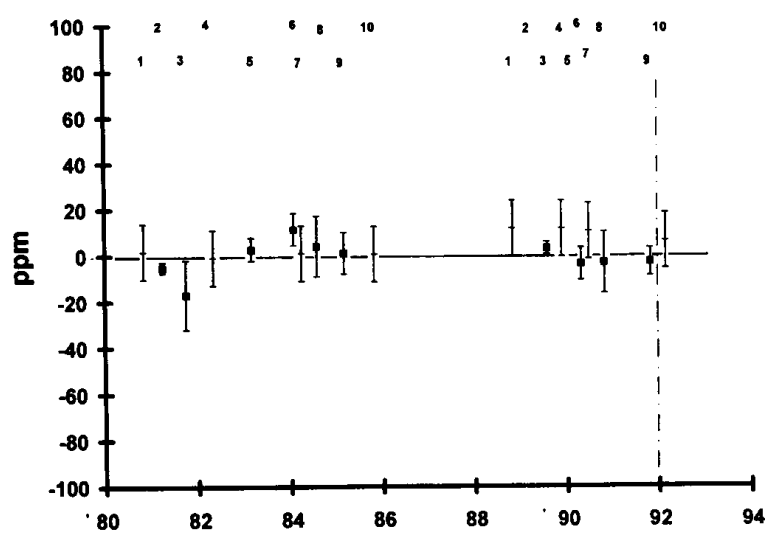

(a)

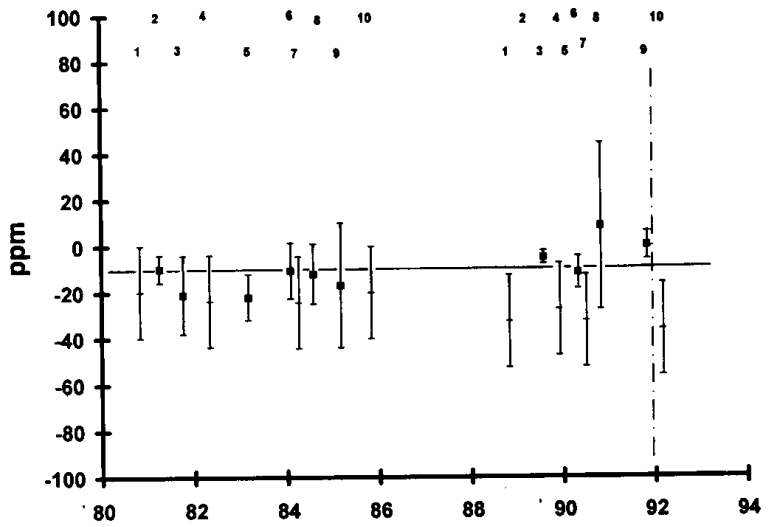

(b)

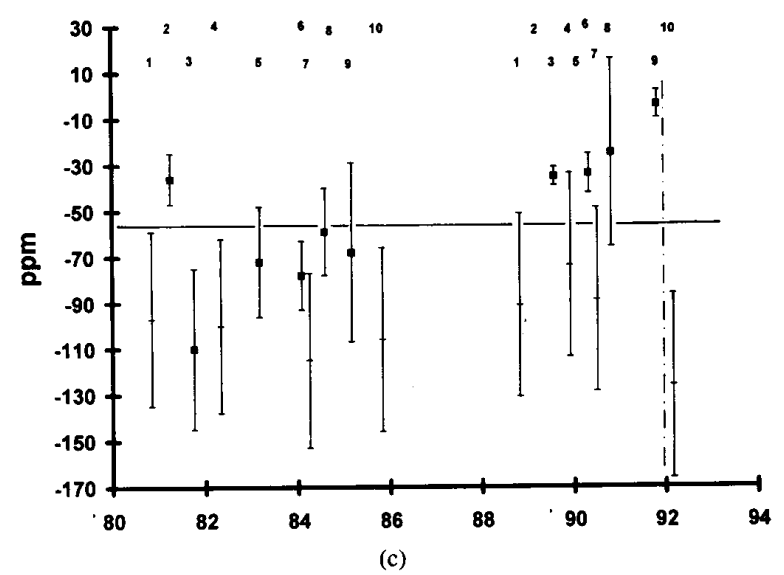

Fig. 5. AC-DC difference and total uncertainty (vertical bar: $1 \sigma$ ) for the 1000-V standard as measured by each laboratory: (a) $40 \mathrm{~Hz}$. (b) $20 \mathrm{kHz}$. (c) $50 \mathrm{kHz}$

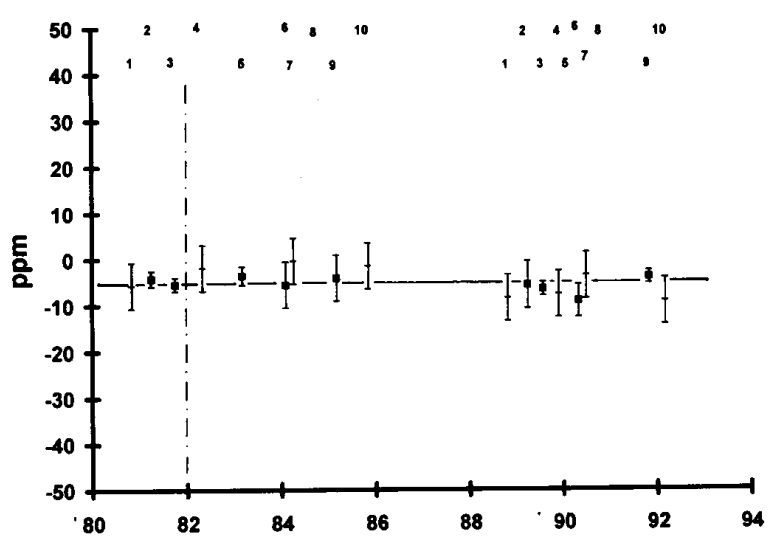

(a)

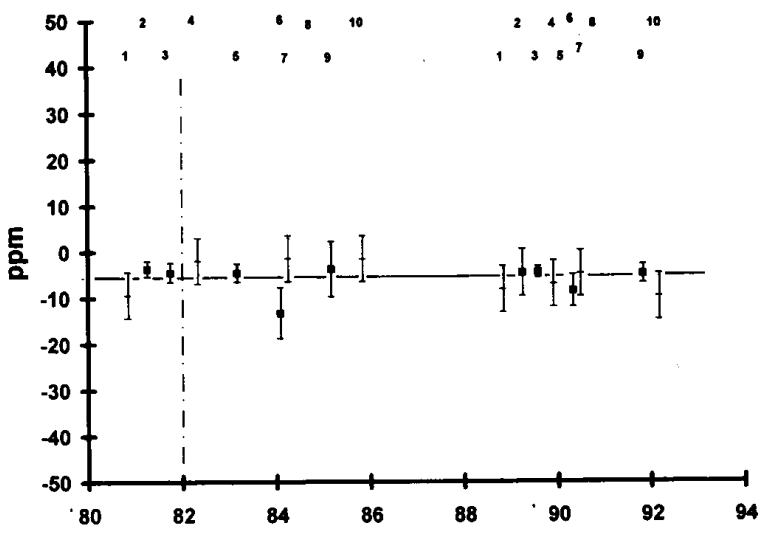

(b)

Fig. 6. AC-DC difference and total uncertainty (vertical bar: $1 \sigma$ ) for the $10-\mathrm{mA}$ standard as measured by each laboratory. (a) $40 \mathrm{~Hz}$. (b) $20 \mathrm{kHz}$. (c) $50 \mathrm{kHz}$. (d) $100 \mathrm{kHz}$ 


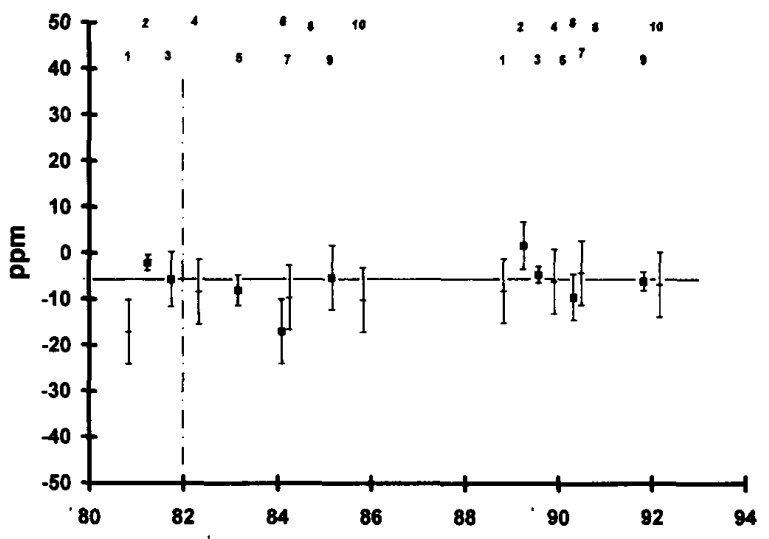

(c)

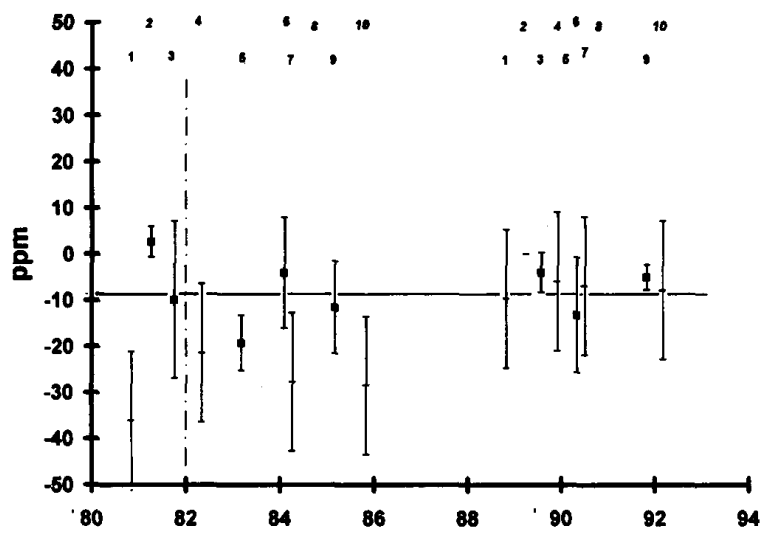

(d)

Fig. 6. (Continued.)

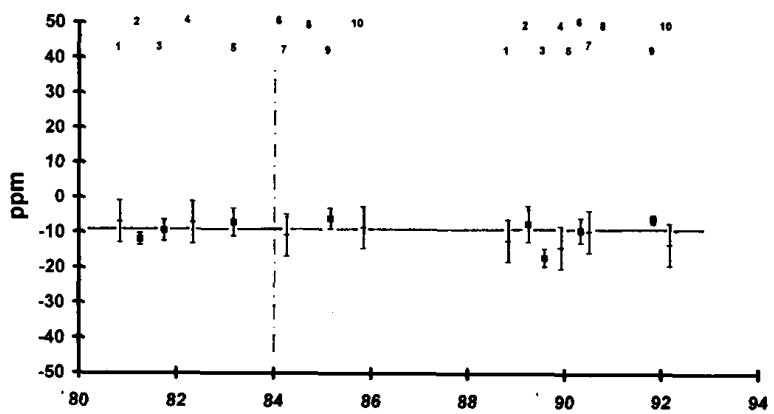

(a)

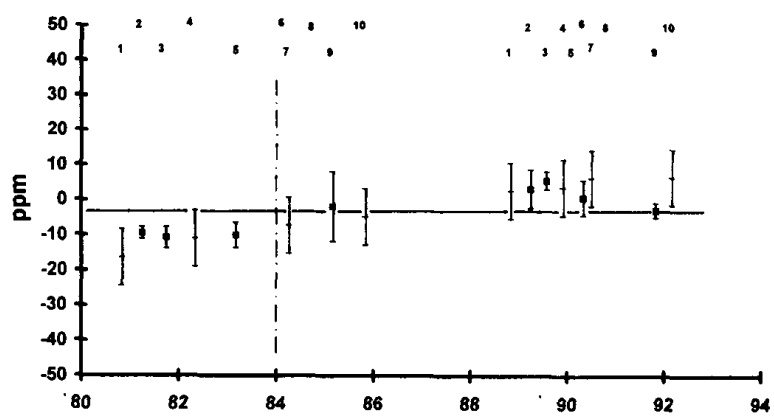

(c)

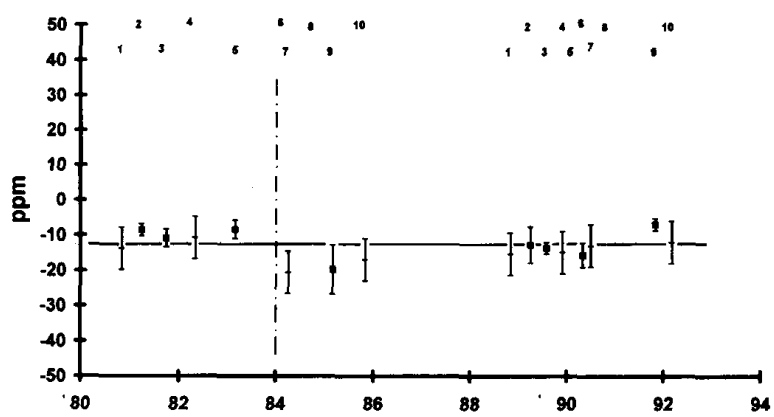

(b)

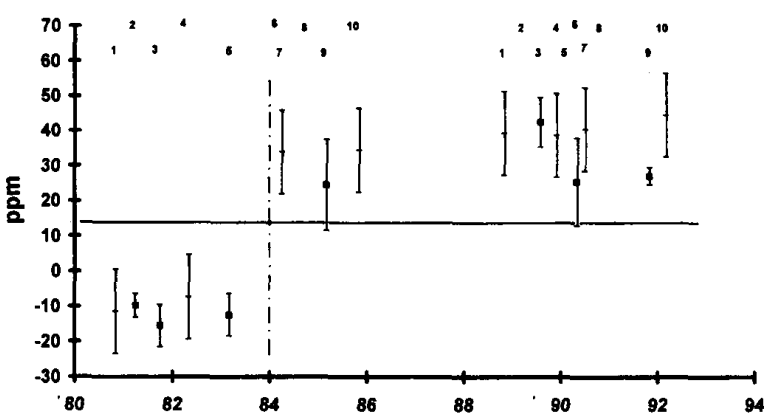

(d)

Fig. 7. AC-DC difference and total uncertainty (vertical bar: $1 \sigma$ ) for the $30-\mathrm{mA}$ standard as measured by each laboratory. (a) $40 \mathrm{~Hz}$. (b) $20 \mathrm{kHz}$. (c) $50 \mathrm{kHz}$. (d) $100 \mathrm{kHz}$.

\section{Conclusions}

From the data obtained in this intercomparison it seems that ac-dc transfer measurements for voltage are in agreement to within some $10 \mathrm{ppm}$ for the lower ranges (up to $100 \mathrm{~V}$ ) and within the audio range (up to $20 \mathrm{kHz}$ ). The agreement degrades to some $50-100 \mathrm{ppm}$ over the full amplitude range and up to $100 \mathrm{kHz}$. At $1 \mathrm{MHz}$ larger discrepancies became evident. For current measurements the results are even more promising with agreement within 5$40 \mathrm{ppm}$.

The long time span has reduced the value of the intercomparison. A number of laboratories have already asked for a possible re-measurement, because they have improved their facilities significantly. Therefore, a new intercomparison is needed in this field. Although lessons should be taken from this comparison before starting a new round, limited comparisons running in parallel with 
TABLE III

Summary of Results Compiled Over All Participants for Each Transfer STANDARD

\begin{tabular}{ccccc}
\hline $\begin{array}{l}\text { Standard } 10 \mathrm{~V} \\
\text { Frequency: }\end{array}$ & $\begin{array}{c}\text { Average: } \\
(\mathrm{ppm})\end{array}$ & $\begin{array}{c}\text { Std. devn. } \\
(\mathrm{ppm})\end{array}$ & $\begin{array}{c}\text { Min. } \\
(\mathrm{ppm})\end{array}$ & $\begin{array}{c}\text { Max. } \\
(\mathrm{ppm})\end{array}$ \\
0.04 & 3.9 & 3.0 & -1.5 & 9.0 \\
20 & -0.7 & 3.2 & -6 & 5.2 \\
50 & -2.8 & 5.0 & -15.5 & 8.7 \\
100 & -4.6 & 8.9 & -26.0 & 19.3 \\
1000 & -44.6 & 60.1 & $-498^{*}$ & 25 \\
& (*not included in calculation)
\end{tabular}

Standard $30 \mathrm{~V}$

\begin{tabular}{|c|c|c|c|c|}
\hline $\begin{array}{l}\text { Frequency: } \\
\qquad(\mathrm{kHz})\end{array}$ & $\begin{array}{c}\text { Average: } \\
\text { (ppm) }\end{array}$ & $\begin{array}{l}\text { Std. devn. } \\
\quad(\mathrm{ppm})\end{array}$ & $\begin{array}{l}\text { Min. } \\
\text { (ppm) }\end{array}$ & $\begin{array}{l}\text { Max. } \\
\text { (ppm) }\end{array}$ \\
\hline $\begin{array}{c}0.04 \\
20 \\
50 \\
100\end{array}$ & $\begin{array}{r}3.4 \\
-1.6 \\
-6.8 \\
-15.7\end{array}$ & $\begin{array}{r}3.5 \\
3.8 \\
6.4 \\
10.0\end{array}$ & $\begin{array}{r}-2.7 \\
-11.4 \\
-21.4 \\
-34.1\end{array}$ & $\begin{array}{r}10.2 \\
4.0 \\
4.0 \\
8.7\end{array}$ \\
\hline \multicolumn{5}{|c|}{ Standard $100 \mathrm{~V}$} \\
\hline $\begin{array}{l}\text { Frequency: } \\
\qquad(\mathrm{kHz})\end{array}$ & $\begin{array}{l}\text { Average: } \\
\text { (ppm) }\end{array}$ & $\begin{array}{l}\text { Std. devn. } \\
\quad(\mathrm{ppm})\end{array}$ & $\begin{array}{c}\text { Min. } \\
\text { (ppm) }\end{array}$ & $\begin{array}{c}\text { Max. } \\
\text { (ppm) }\end{array}$ \\
\hline $\begin{array}{l}0.04 \\
20 \\
50 \\
100\end{array}$ & $\begin{array}{r}4.7 \\
-6.4 \\
-20.8 \\
-42.4\end{array}$ & $\begin{array}{r}3.6 \\
4.0 \\
10.3 \\
21.4\end{array}$ & $\begin{array}{r}-2.0 \\
-13.8 \\
-38.7 \\
-73.5\end{array}$ & $\begin{array}{r}13.2 \\
0.1 \\
-10.3 \\
-13.0\end{array}$ \\
\hline \multicolumn{5}{|c|}{ Standard $300 \mathrm{~V}$} \\
\hline $\begin{array}{l}\text { Frequency: } \\
\qquad(\mathrm{kHz})\end{array}$ & $\begin{array}{l}\text { Average: } \\
\text { (ppm) }\end{array}$ & $\begin{array}{l}\text { Std. devn. } \\
\text { (ppm) }\end{array}$ & $\begin{array}{l}\text { Min. } \\
\text { (ppm) }\end{array}$ & $\begin{array}{c}\text { Max. } \\
\text { (ppm) }\end{array}$ \\
\hline $\begin{array}{c}0.04 \\
20 \\
50 \\
100\end{array}$ & $\begin{array}{r}3.6 \\
-21.9 \\
-37.1 \\
-4.9\end{array}$ & $\begin{array}{r}3.9 \\
12.2 \\
22.7 \\
33.6\end{array}$ & $\begin{array}{r}-3.1 \\
-34.0 \\
-66.0 \\
-55.0\end{array}$ & $\begin{array}{r}12.55 \\
1.0 \\
-9.0 \\
40.0\end{array}$ \\
\hline \multicolumn{5}{|c|}{ Standard $1000 \mathrm{~V}$} \\
\hline $\begin{array}{c}\text { Frequency: } \\
\text { (kHz) } \\
0.04 \\
20 \\
50\end{array}$ & $\begin{array}{c}\text { Average: } \\
\text { (ppm) } \\
-0.5 \\
-11.6 \\
-56.4\end{array}$ & $\begin{array}{c}\text { Std. devn. } \\
\text { (ppm) } \\
7.2 \\
9.7 \\
37.0\end{array}$ & $\begin{array}{c}\text { Min. } \\
\text { (ppm) } \\
-17.0 \\
-36.3 \\
-126.3\end{array}$ & $\begin{array}{r}\text { Max. } \\
\text { (ppm) } \\
11.6 \\
8.3 \\
-4.0\end{array}$ \\
\hline \multicolumn{5}{|c|}{ Standard $10 \mathrm{~mA}$} \\
\hline $\begin{array}{l}\text { Frequency: } \\
\qquad(\mathrm{kHz})\end{array}$ & $\begin{array}{c}\text { Average: } \\
\text { (ppm) }\end{array}$ & $\begin{array}{l}\text { Std. devn. } \\
\text { (ppm) }\end{array}$ & $\begin{array}{l}\text { Min. } \\
(\mathrm{ppm})\end{array}$ & $\underset{\text { (ppm) }}{\operatorname{Max} .}$ \\
\hline $\begin{array}{c}0.04 \\
20 \\
50 \\
100\end{array}$ & $\begin{array}{l}-5.3 \\
-5.8 \\
-6.5 \\
-9.1\end{array}$ & $\begin{array}{l}3.0 \\
3.9 \\
5.5 \\
7.1\end{array}$ & $\begin{array}{r}-9.3 \\
-13.3 \\
-17.1 \\
-36.1\end{array}$ & $\begin{array}{r}-0.4 \\
-1.5 \\
1.7 \\
2.7\end{array}$ \\
\hline \multicolumn{5}{|c|}{ Standard $30 \mathrm{~mA}$} \\
\hline $\begin{array}{l}\text { Frequency: } \\
\quad(\mathrm{kHz})\end{array}$ & $\begin{array}{c}\text { Average: } \\
(\mathrm{ppm})\end{array}$ & $\begin{array}{l}\text { Std. devn. } \\
\quad(\mathrm{ppm})\end{array}$ & $\underset{(\mathrm{ppm})}{\operatorname{Min} .}$ & $\begin{array}{l}\text { Max. } \\
(\mathrm{ppm})\end{array}$ \\
\hline $\begin{array}{c}0.04 \\
20 \\
50 \\
100\end{array}$ & $\begin{array}{r}-9.3 \\
-12.4 \\
-3.2 \\
13.5\end{array}$ & $\begin{array}{r}5.1 \\
6.1 \\
6.1 \\
22.0\end{array}$ & $\begin{array}{l}-17.0 \\
-20.6 \\
-16.4 \\
-15.5\end{array}$ & $\begin{array}{r}-5.9 \\
-7.0 \\
6.5 \\
44.6\end{array}$ \\
\hline
\end{tabular}

TABLE IV

SUMMARY OF TYPE A UNCERTAINTY RELATIVE TO TYPE B UNCERTAINTY FOR A NUMBER OF STANDARDS

\begin{tabular}{ccccc}
\hline \multicolumn{5}{c}{ Frequency $(\mathrm{kHz})$} \\
Voltage(V): & 0.04 & 20 & 100 & 1000 \\
10 & $\leq 0.1$ & $\leq 0.1$ & $\leq 0.1$ & $\leq 0.1-0.25$ \\
100 & $<0.1-0.7$ & $0.1-0.3$ & $<0.1-0.3$ & \\
1000 & $0.1-1.0$ & $0.1-0.5$ & & \\
Current: & & & & \\
$10 \mathrm{~mA}$ & $0.1-1.0$ & $0.1-0.5$ & $<0.1-0.2$ \\
\hline
\end{tabular}

some linkage (e.g., a laboratory participating in more than one comparison) might be a good alternative. Altogether, the intercomparison provides unprecedented information about the worldwide measuring capability of the national standards laboratories and the consistency of their results, thereby establishing the necessary basis for mutual recognition of calibration certificates.

\section{ACKNOWLEDGMENT}

The author would like to thank Dr. C. J. P. M. Harmans for organizing the first round of this comparison, $\mathrm{J}$. J Schmitt and J. T. Dessens for carrying out the measurements at VSL, and all participants for providing the details of their measurements.

\section{REFERENCES}

[1] O. P. Galakhova, S. Harkness, F. L. Hermach, H. Hirayama, P. Martin, T. H. Rozdestvenskaya, and E. S. Williams, "An international comparison of thermal converters as ac-dc transfer standards," IEEE Trans. Instrum. Meas., vol. IM-29, pp. 396-399, Dec. 1980.

[2] C. Harmans, "Intercomparison measurements of thermal ac-dc transfer standards," EUR 11567, Office for Official Publications of the European Communities, L-2985 Luxembourg, 1988.

[3] F. L. Hermach, J. R. Kinard, and J. R. Hastings, "Multijunction thermal converters as the NBS primary ac-dc transfer standards for ac current and voltage measurement," IEEE Trans. Instrum. Meas., vol. IM36, pp. 300-306, June 1987.

[4] M. Klonz, "ac-dc voltage transfer difference of the PTB-multijunction thermal converter in the frequency range from $10 \mathrm{~Hz}$ to $100 \mathrm{kHz}$,' IEEE Trans. Instrum. Meas., vol. IM-36, pp. 360-367, June 1987.

[5] T. Matsumura and R. F. Clark, "ac-dc difference measurements on thermal voltage converters at NRC," IEEE Trans. Instrum. Meas. vol. IM-36, pp. 333-336, June 1987.

[6] J. R. Kinard, J. R. Hastings, T. E. Lipe, and C. B. Childers, "ac-dc difference calibrations," NIST Special Publ. 250-17, U.S. Gov. Printing Office, May 1989.

[7] M. Nomair and K. J. P. M. Harmans, "High accuracy calculable acdc transfer standards for the LF- $30 \mathrm{MHz}$ frequency range," IEEE Trans. Instrum. Meas., vol. 38, pp. 342-345, Apr. 1989.

[8] M. Klonz and T. Weimann, "Accurate thin film multijunction thermal converter on a silicon chip," IEEE Trans. Instrum. Meas., vol. 38, pp. 335-337, Apr. 1989.

[9] J. R. Kinard and T. X. Cai, "Determination of ac-dc difference in the 0.1-100 MHz frequency range," IEEE Trans. Instrum. Meas., vol. 38 , pp. $360-367$, Apr. 1989 